\title{
Use of organic waste biochar as an innovative alternative for increasing agricultural productivity in small rural communities
}

\author{
Uso de biocarvão de resíduos orgânicos como alternativa inovadora para o aumento da produtividade \\ agrícola em pequenas comunidades rurais
}

Uso de biocarbón de residuos orgánicos como alternativa innovadora para aumentar la productividad agrícola en pequeñas comunidades rurales

Received: 03/12/2021 | Reviewed: 03/19/2021 |Accept: 03/24/2021 | Published: 04/01/2021

\author{
Maria Isidória Silva Gonzaga \\ ORCID: https://orcid.org/0000-0002-7884-6386 \\ Universidade Federal of Sergipe, Brazil \\ E-mail: mariaisisilva@gmail.com \\ Danyelle Chaves Figueiredo de Souza \\ ORCID: https://orcid.org/0000-0001-6873-8165 \\ Universidade Federal of Sergipe, Brazil \\ E-mail: danyelle.ef@gmail.com \\ José Carlos de Jesus Santos \\ ORCID: https://orcid.org/0000 000310881027 \\ Universidade Federal of Sergipe, Brazil \\ E-mail: josecarlos17san@gmail.com
}

\begin{abstract}
Biochar, pyrolyzed organic waste for agronomic and environmental purposes, is a viable alternative to improve soil quality in small farm areas in the state of Sergipe, where there is a shortage of water and chemical inputs. This study evaluated the effect of single and simultaneous application of doses $\left(\mathrm{t} \mathrm{ha}^{-1}\right)$ of sewage sludge (SS) and dry coconut shell (CS) on some soil properties and sunflower growth and nutrition (Helianthus annuus L.), in São Cristóvão-SE. The experiment was carried out in a completely randomized scheme, with 6 treatments (1. SE60CS0; 2. SE30CS0; 3. SE20CS10; 4. SE10CS20; 5. SE0CS30; 6. Control (without biochar) and 5 repetitions. In the soil, $\mathrm{pH}$, electrical conductivity, organic carbon, and $\mathrm{P}$, $\mathrm{K}$, and $\mathrm{Na}$ concentrations were determined. In the plant, biomass, height, chlorophyll content, and $\mathrm{N}$, P, and $\mathrm{K}$ were evaluated. Alone, coconut biochar increased the soil $\mathrm{pH}$ but reduced plant $\mathrm{N}$. The sludge biochar did not increase soil $\mathrm{pH}$ but improved the soil $\mathrm{N}$ and P levels, plant growth (25\%), and inflorescence (33\%), indicating greater benefits of joint application. In addition to improving productivity, biochar, both from sewage sludge and dry coconut shell, can improve the destination and management of these residues and, at the same time, promote the recycling of nutrients in soil.
\end{abstract}

Keywords: Sustainable development; Organic waste; Pyrolysis; Recycling.

\section{Resumo}

O biocarvão, resíduo orgânico pirolisado para fins agronômicos e ambientais, é uma alternativa viável para melhorar a qualidade do solo em pequenas áreas agrícolas no estado de Sergipe, onde há escassez de água e de insumos químicos. Este estudo avaliou o efeito da aplicação individual e simultânea de doses $\left(\mathrm{t} \mathrm{ha}^{-1}\right)$ de biocarvão de lodo de esgoto (LE) e casca de coco seco (CS) em algumas propriedades do solo e no crescimento e nutrição de girassol (Helianthus annuus L.), em São Cristóvão-SE. O experimento foi desenvolvido em esquema inteiramente casualizado, com 6 tratamentos (1. $\mathrm{LE}_{60} \mathrm{CS}_{0}$; 2. $\mathrm{LE}_{30} \mathrm{CS}_{0} ; 3$. $\mathrm{LE}_{20} \mathrm{CS}_{10} ; 4$. $\mathrm{LE}_{10} \mathrm{CS}_{20} ; 5$. $\mathrm{LE}_{0} \mathrm{CS}_{30} ; 6$. Controle (sem biocarvão) e 5 repetições. No solo, foram determinados pH, condutividade elétrica, carbono orgânico e concentrações de P, K e Na. Na planta, foram avaliados biomassa, altura, teor de clorofila e concentrações de N, P e K. Sozinho, o biocarvão de coco aumentou o pH do solo, mas reduziu o N na planta. O biocarvão de lodo não aumentou o pH do solo, mas melhorou os níveis de $\mathrm{N}$ e $\mathrm{P}$ no solo e na planta. Já a combinação dos dois biocarvões aumentou o pH do solo, a biomassa da planta (em 25\%) e da inflorescência (em 33\%), indicando maiores benefícios da aplicação conjunta. Além de melhorar a produtividade, o uso de biocarvão, tanto de lodo de esgoto quanto de casca de coco seco, pode melhorar o destino e o manejo desses resíduos e, ao mesmo tempo, promover a reciclagem de nutrientes no solo.

Palavras-chave: Desenvolvimento sustentável; Resíduos orgânicos; Pirólise; Reciclagem. 


\section{Resumen}

El biocarbón, residuo orgánico pirolizado con fines agronómicos y ambientales, es en alternativa viable para mejorar la calidad del suelo en pequeñas áreas agrícolas en el estado de Sergipe, donde hay escasez de água y de insumos químicos. El presente estudio evaluó el efecto de la aplicación individual y simultánea de dosis ( t ha-1) de lodos de depuradora (LE) y cáscara de coco seca (CS) sobre algunas propiedades del suelo y sobre el crecimiento y nutrición del girasol (Helianthus annuиs L.), en São Cristóvão-SE. El experimento se desarrolló en un esquema completamente al azar, con 6 tratamientos (1. LE60CS0; 2. LE30CS0; 3. LE20CS10; 4. LE10CS20; 5. LE0CS30; 6. Control (sin biochar) y 5 repeticiones. En el suelo, pH Se determinó la conductividad eléctrica, el carbono orgánico y las concentraciones de P, K y Na. En la planta se evaluó la biomasa, la altura, el contenido de clorofila y las concentraciones de N, P y K. Solo, el biocarbón de coco aumentó el pH del suelo, pero redujo o $\mathrm{N}$ en la planta. El biocarbón de lodos no aumentó el pH del suelo, pero sí mejoró los niveles de $\mathrm{N}$ y $\mathrm{P}$ en el suelo y en la planta.) e inflorescencia (en un 33\%), lo que indica mayores beneficios de la articulación. aplicación Además de mejorar la productividad, el uso de biocarbón, tanto lodos de depuradora como cáscara de coco seca, puede mejorar el destino y manejo de estos residuos y, al mismo tiempo, promover el reciclaje de nutrientes en el suelo.

Palabras clave: Desarrollo sustentable; Residuo orgánico; Pirólisis; Reciclaje.

\section{Introduction}

Small farms in Sergipe represent a significant branch of the agricultural sector and are responsible for a large part of its food supply. In these areas, soil management still follows traditional and, in most cases, non-conservationist techniques. In this scenario, farming practices and technologies to increase and sustain food production without degrading the ecosystems are much needed. Therefore, the use of innovative technologies such as biochar has the potential to improve the quality of agro-ecosystems and contribute to environmental sustainability (Das, et al., 2020). This is because biochar is a charcoal-like material produced to be used as a soil amendment and conditioner. Its soil application improves soil quality, enhances carbon sequestration, reduces atmospheric emissions, and increases plant productivity (Abdelhafez, et al., 2017; Yu, et al., 2019; Das, et al., 2020). The conversion of organic wastes of any kind into biochar offers a viable alternative to waste disposal with additional economic and environmental benefits (Ding, et al., 2017; Gonzaga, et al., 2017).

Plant-derived lignocellulosic residues such as wood chips, coconut shells, and sugarcane bagasse result in biochar with low nutrient content; however, they present high porosity and surface area, which could be preferentially an advantage as a soil conditioner (Batista, et al., 2018). Conversely, animal-derived wastes such as sewage sludge and manure result in biochar with high nutrient content, especially N and P, making it a suitable soil amendment (Silva, et al., 2017; Paz-Ferreiro, et al., 2018; Hossain, et al., 2020).

Soil amendment in the form of fertilizers has been the main source of plant nutrients; however, fossil fuel-based fertilizers are not environmentally friendly and cost-effective and are not easily available to small farmers. In that sense, sewage sludge and manure biochar can become a valuable resource for agriculture and an alternative to reduce the use of inorganic nutrient sources while improving the overall soil quality (Paz-Ferreiro, et al., 2018). Hossain, et al. (2010) applied $10 \mathrm{t} \mathrm{ha}^{-1}$ of sewage sludge biochar to soil and observed a $64 \%$ increase in cherry tomatoes' production. Their results were related to increased nutrient availability and soil chemical conditions. Yuan, et al. (2016) observed an increase in the concentrations of N, P, and K of a Typic Plinthudult soil after the addition of sewage sludge biochar, suggesting that electrostatic attraction forces might play a role in retaining $\mathrm{NH}_{4}{ }^{+}$and $\mathrm{K}^{+}$ over a long period of time. Gonzaga, et al. (2019) reported an increasing water use efficiency and plant growth in Brassica juncea plants in sewage sludge biochar treated soils.

Lignified residues-derived biochar can be broadly used in small farms due to the abundance of biomass. Even though this kind of biochar may not be an as good source of nutrients as the sewage sludge, it can increase the soil carbon content and improve water and nutrient retention (Albuquerque, et al., 2014; Yousef, et al., 2016; Batista, et al.,2018). Gonzaga, et al. (2021) observed 
increased plant dry biomass and reduced $\mathrm{N}$ and $\mathrm{P}$ availability after growing maize in soil treated with coconut husk biochar. Other studies report different results, as in Hossain, et al. (2020), who observed increased nutrient availability in biochar treated soils. The variation in the results is related to the type of feedstock, pyrolysis process, soil conditions, and climate.

Biochar's intrinsic characteristics, such as $\mathrm{pH}$, electrical conductivity, nutrient concentrations, porosity, surface area and water retention capacity, may have distinct effects in the soil, water resources, and plant growth. Therefore, we hypothesize that applying a biochar mix with different characteristics could result in improved soil quality and plant performance compared to the application of a sole source of biochar. To prove that, a greenhouse study was undertaken to evaluate the agronomic potential of coconut shell and sewage sludge biochar, used both alone and in a different combination, on soil properties and the growth and nutrition of sunflower plants (Helianthus annus L.) in a loamy sand soil.

\section{Materials and Methods}

\section{Soil and biochar characterization}

Soil samples $(0-20 \mathrm{~cm})$ were collected from the Federal University of Sergipe experimental station, Northeast Brazil (about S $10^{\circ} 55^{\prime} 46^{\prime \prime} ;$ N $37^{\circ} 06^{\prime} 13^{\prime \prime}$ ). The soil was classified according to the USDA Soil Taxonomy (Soil Survey Staff, 2014) as Yellow Ultisol and presented the following characteristics: $\mathrm{pH}: 4.64$, EC: $0.63 \mathrm{dS} \mathrm{m}^{-1}$ à $25^{\circ} \mathrm{C}, 11.6 \mathrm{~g} \mathrm{OM} \mathrm{dm}^{-3}, \mathrm{CEC}: 1.88 \mathrm{cmolc} \mathrm{kg}^{-1}, 1.82$ $\mathrm{mg} \mathrm{P} \mathrm{kg}{ }^{-1}, 25.4 \mathrm{mg} \mathrm{K} \mathrm{kg}{ }^{-1}, 0.45 \mathrm{cmol} \mathrm{Al} \mathrm{kg}{ }^{-1}, 0.72 \mathrm{cmol} \mathrm{Ca} \mathrm{kg}{ }^{-1}, 0.65 \mathrm{cmol} \mathrm{Mg} \mathrm{kg}{ }^{-1}$. Physical properties were: Sand: 71.6\%, Silt: 13.4\%, Clay: $15.0 \%$ (Silva, 2009).

Coconut shells and dried sewage sludge were used to make biochar in a slow pyrolysis reactor, a Top-Lit Updraft oven, where the volatile byproducts of pyrolization are released (Nsamba, et al., 2015), at a temperature of $550^{\circ} \mathrm{C}$. Biochar was ground, sieved to $2 \mathrm{~mm}$ particle size, and evaluated through proximate analysis (Ash, volatile matter, and fixed C), ultimate analysis (C, N, $\mathrm{H}$, and O) (ASTM D175284), and concentration of $\mathrm{P}, \mathrm{K}$, and Na. Biochar $\mathrm{pH}$ and electrical conductivity were also determined (Gasking, et al., 2008). Biochar characteristics are presented in Table 1.

Table 1. Characteristics of the biochar from coconut husks and sewage sludge. $\mathrm{FC}=$ fixed carbon; VM=volatile matter

\begin{tabular}{lcc}
\hline Biochar characteristics & Coconut husks & Sewage sludge \\
\hline Ash (\%) & 10.1 & 26.0 \\
Volatile matter (\%) & 15.0 & 54.1 \\
Fixed C (\%) & 75.0 & 20.2 \\
$\mathrm{C}(\%)$ & 79.8 & 45.5 \\
$\mathrm{~N}(\%)$ & 0.42 & 7.40 \\
$\mathrm{H}(\%)$ & 2.21 & 4.25 \\
$\mathrm{O}(\%)$ & 7.42 & 16.1 \\
$\mathrm{P}(\%)$ & 0.10 & 0.55 \\
$\mathrm{pH}$ & 10.0 & 7.30 \\
$\mathrm{EC}\left(\mathrm{dS} \mathrm{m}{ }^{-1}, 25^{\circ} \mathrm{C}\right)$ & 0.43 & 10.3 \\
\hline
\end{tabular}

Source: Authors. 


\subsection{Experimental set up}

This is a scientific research paper in which the data were collected from experiment units based on a statistical arrangement (Pereira, et al, 2018).

The experiment was carried out in a greenhouse environment at $28^{\circ} \mathrm{C}$ and as a completely randomized design with six treatments and 5 replicates. The treatments were biochar alone or in combination, as follows: 1 . Sewage sludge biochar at a rate of application of 60 ton ha- ${ }^{-1}$ (SS60CS0); 2. Sewage sludge biochar at an application rate of 30 ton ha $^{-1}$ (SS30CS0); 3. Sewage sludge biochar at an application rate of 20 ton ha ${ }^{-1}$ mixed with coconut shell biochar at an application rate of 10 ton ha $^{-1}$ (SS20CS10); 4. Sewage sludge biochar at an application rate of 10 ton ha ${ }^{-1}$ mixed with coconut shell biochar at an application rate of 20 ton ha (SS10CS20); 5. Coconut shell biochar at an application rate of 30 ton ha- ${ }^{-1}$ (SS0CS30); 6. Control (no biochar addition).

We used $25 \mathrm{~L}$ plastic pots with $50 \mathrm{~cm}$ height, $17.5 \mathrm{~cm}$ diameter at the bottom, and $29.5 \mathrm{~cm}$ diameter at the top. Biochar was applied only in the top $20 \mathrm{~cm}$ height and mixed with the soil to mimic a field condition. The pots' soil was watered to $70 \%$ field capacity and was allowed to equilibrate for one week before planting. Three sunflower seeds were sown in each pot. Plants were allowed to grow for 55 days when all the inflorescences were opened. Chlorophyll content, plant height, and colon diameter were measured. Chlorophyll content of the mid-section fully expanded leaves was measured using a hand-held chlorophyll meter (SPAD meter). Plants were then harvested, washed with tap water, rinsed with DI water, dried in a $60^{\circ} \mathrm{C}$ oven for approximately 48 hours, and weighed to determine the dry biomass.

Plant samples (leaves) were digested in a hot block digestion system, following the $\mathrm{N}$ determination TKN protocol (Bremner, 1996). Analysis of total $\mathrm{N}$ was performed after steam distillation of ammonia. Total $\mathrm{P}$ concentration in plant samples was determined in the TKN extracts using the molybdenum blue method (Murphey \& Riley, 1962). Plant samples were acid-digested with 1:1 nitric acid in the hot block system according to the USEPA 3050 protocol to determine $\mathrm{K}$ and Na concentrations by flame photometry (Silva, 2009).

Disturbed soil samples were collected from the $20 \mathrm{~cm}$ layer at harvest, dried, sieved to $2 \mathrm{~mm}$ screen, and analyzed for $\mathrm{pH}$, EC, organic C, and concentration of extractable P, K, Ca, Mg, and Na. Soil pH was determined in a 1:5 (w/w) biochar: water ratio after $1.5 \mathrm{~h}$ shaking in a reciprocating shaker and $1 \mathrm{~h}$ equilibration (Gasking, et al., 2008). Electric conductivity (EC) was then determined in the same extract. Soil organic carbon was determined by the Walkley-Black Method (Nelson \& Sommers, 1982). The concentration of extractable $\mathrm{P}, \mathrm{K}$, and $\mathrm{Na}$ in soil samples was determined after extraction with Mehlich $\left(\mathrm{HCl} 0.05 \mathrm{~mol} \mathrm{~L}^{-1}+\mathrm{H}_{2} \mathrm{SO}_{4}\right.$ $\left.0.0125 \mathrm{~mol} \mathrm{~L}^{-1}\right)$.

\subsection{Statistical Analysis}

Results are reported as the means of five replicates. A one-way Analysis of Variance (ANOVA) was performed to determine whether there were significant differences between the treatment means using SISVAR software package (Ferreira, 2011). Post hoc comparisons were conducted using Tukey's multiple range test at $\mathrm{P}<0.05$.

\section{Results and Discussion}

\subsection{Biochar characteristics}

The feedstock used in this study resulted in biochars with different chemical characteristics (Table 1). The SSB presented higher ash and volatile matter and lower fixed $\mathrm{C}$ content than the CSB, which is related to the higher $\mathrm{pH}$ of the CSB and the lower $\mathrm{C} / \mathrm{N}$ ratio of the SSB. Based on these characteristics, the CSB is more suitable as a soil conditioner and a liming agent. This biochar can 
remain in the soil for a longer period of time due to its high fixed C content compared to the SSB. Conversely, the SSB will likely have a shorter lifetime and a discrete impact on soil $\mathrm{pH}$ but could be a good source of $\mathrm{N}$ and $\mathrm{P}$, although the high EC may cause some salinization problems if applied at high rates in soil. Therefore, due to the two biochars' very distinct characteristics, it is rather wise the jointed application.

\subsection{Effect of biochar on soil characteristics}

The different biochar treatments significantly $(\mathrm{P}<0.05)$ affected the soil characteristics (Table 2). Application of a sole source sewage sludge biochar (SS60CS0 e SS30CS0) did not affect soil pH, which was somehow expected due to the low pH of this biochar (7.3). Conversely, the CSB significantly increased soil $\mathrm{pH}$ when applied either as a sole source of biochar or in combination with SSB, probably due to its higher $\mathrm{pH}$ (10.0), showing an effective improvement in the soil reaction. Considering that most plant species' ideal soil $\mathrm{pH}$ range is from 5.5-6.5, only the treatment SSOCS30 was able to raise soil $\mathrm{pH}$ to an adequate level effectively.

Table 2. $\mathrm{pH}$, electrical conductivity (EC), Total oxidizable carbon ( $\mathrm{SOM}$ ), and concentration of extractable phosphorus (P), potassium $(\mathrm{K})$, and sodium $(\mathrm{Na})$ in a Ultisol amended with coconut shell biochar and sewage sludge biochar, either alone or combined in different proportions, and cultivated with sunflower plants (Helianthus annuus L). *: means followed by the same letter in a column are not significantly different $(\mathrm{P}<0.05)$ by the Tukey Test.

\begin{tabular}{lcccccc}
\hline Treatments & $\mathrm{pH}$ & $\mathrm{EC}$ & $\mathrm{TOC}$ & $\mathrm{P}$ & $\mathrm{K}$ & $\mathrm{Na}$ \\
\hline & & $\mathrm{dS} \mathrm{m}$ & $--\mathrm{g} \mathrm{kg}^{-1}--$ & ------------ & $\mathrm{mg} \mathrm{kg}^{-1}-------------$ \\
Control & $4.90 \mathrm{~b}^{*}$ & $0.20 \mathrm{c}$ & $8.90 \mathrm{~b}$ & $37.8 \mathrm{c}$ & $70.6 \mathrm{c}$ & $137 \mathrm{~b}$ \\
$\mathrm{SS}_{60} \mathrm{CS}_{0}$ & $5.13 \mathrm{ab}$ & $0.34 \mathrm{a}$ & $14.4 \mathrm{a}$ & $86.1 \mathrm{a}$ & $100 \mathrm{~b}$ & $181 \mathrm{a}$ \\
$\mathrm{SS}_{30} \mathrm{CS}_{0}$ & $5.11 \mathrm{ab}$ & $0.24 \mathrm{~b}$ & $8.30 \mathrm{~b}$ & $52.8 \mathrm{~b}$ & $95.1 \mathrm{~b}$ & $132 \mathrm{~b}$ \\
$\mathrm{SS}_{20} \mathrm{CS}_{10}$ & $5.29 \mathrm{a}$ & $0.18 \mathrm{c}$ & $10.3 \mathrm{~b}$ & $47.9 \mathrm{~b}$ & $98.7 \mathrm{~b}$ & $138 \mathrm{~b}$ \\
$\mathrm{SS}_{10} \mathrm{CS}_{20}$ & $5.35 \mathrm{a}$ & $0.18 \mathrm{c}$ & $10.0 \mathrm{~b}$ & $31.6 \mathrm{~d}$ & $102 \mathrm{~b}$ & $136 \mathrm{~b}$ \\
$\mathrm{SS}_{0} \mathrm{CS}_{30}$ & $5.61 \mathrm{a}$ & $0.17 \mathrm{c}$ & $10.9 \mathrm{~b}$ & $10.3 \mathrm{e}$ & $121 \mathrm{a}$ & $137 \mathrm{~b}$ \\
\hline
\end{tabular}

Source: Authors.

The liming effect is one of the most desirable biochar characteristics, especially in acidic soils of the tropics. However, besides the influence of the type of biochar, the results depend on the buffering capacity of the soil, as observed by Albuquerque, et al. (2014) after the application of different types of biochar from agricultural wastes at 30-ton ha ${ }^{-1}$ to a Haplic Luvisol with low buffering capacity and $\mathrm{pH}$ 6.5. The authors found a significant increase in soil $\mathrm{pH}$ to the point that could compromise soil nutrients' availability. In the present study, biochar was applied to acidic soil ( $\mathrm{pH} 4.9)$ with a moderate buffering capacity associated with organic matter and kaolinite type clay, which probably may have played a role in resisting a high increase in soil $\mathrm{pH}$. Although the significant increase in soil $\mathrm{pH}$ after application of CSB was rather discrete in the present study (pH 5.61), this biochar's liming effect is something to be considered beneficial. This is because the excessive increase in soil $\mathrm{pH}(\mathrm{pH}>7)$ may cause precipitation of important macronutrients such as $\mathrm{P}$ and $\mathrm{Ca}$ and decrease micronutrients' availability, which could probably impair proper plant growth.

The soil EC varied from 0.17 to $0.34 \mathrm{dS} \mathrm{m}^{-1}$. The SSB, regardless of the rate of application, was the only treatment that influenced the EC, which was likely due to the higher concentration of $\mathrm{P}, \mathrm{K}$, and $\mathrm{Na}$ in this biochar treatment (Table 2); however, 
the EC values did not surpass the threshold level of $1.1 \mathrm{dS} \mathrm{m}^{-1}$, and therefore, it would not be a limitation for the use of this biochar in soil.

The analysis of the total oxidizable carbon (TOC) showed that the addition of biochar had a small effect on the soil carbon labile fraction, suggesting that biochar management will not increase $\mathrm{CO}_{2}$ emissions from agricultural areas; instead, it will contribute to carbon sequestration in soil. The effect of biochar on the oxidizable fraction of $\mathrm{C}$ in soil depends on the type of biochar and application rate. In the present study, the SSB application at a rate of $60 \mathrm{t} \mathrm{ha}^{-1}$ significantly increased TOC content. A similar result was reported by Yousef, et al. (2016), who applied wood biochar into the soil and found a three-fold increase in the TOC content after 120 days incubation period. Nonetheless, most biochars have reduced labile carbon content, which accounts for its high recalcitrance and soil stability (Hossain, et al., 2020).

The biochar treatments significantly influenced the concentration of the available P and $\mathrm{K}$ in the soil. Increasing the SSB rate significantly increased the availability of $\mathrm{P}$ and $\mathrm{K}$ in the soil, confirming its benefits as a soil amendment. Conversely, increasing the amount of CSB, decreased the availability of P. Application of 30-ton $\mathrm{ha}^{-1}$ of CSB reduced P concentration compared to the control, which raises concern regarding the use of CSB as a soil conditioner, especially in soil with high P adsorption capacity. All biochar treatments significantly increased $\mathrm{K}$ availability, especially the highest rate of application of the CSB. Therefore, the combination of the two biochars did not affect EC, TOC, and Na concentration, which could be of real concern; however, the joint aplication increased soil $\mathrm{pH}$ and the concentrations of $\mathrm{P}$ and $\mathrm{K}$ levels in soil, suggesting an improvement in soil quality, contributing to plant growth and nutrition.

\subsection{Effect of biochar on plant growth}

The effect of biochar on plant growth depended mostly on biochar properties and its ability to promote changes in soil quality and nutrient availability. In the present study, biochar from coconut shell (CSB) and sewage sludge (SSB) caused different impacts on sunflower growth and nutrition (Tables 3 and 4). Regardless of the application form, biochar did not affect plant height and stem diameter (Table 3). Similarly, the treatments SS30CS0 and SSOCS30 did not affect shoot biomass, suggesting that 30-ton $\mathrm{ha}^{-1}$ of a sole source of biochar was not enough to promote a significant increase in plant biomass. In fact, at a low rate of application, the effect of biochar on plant growth tends to be discrete, as was observed in the studies of Albuquerque, et al. (2014) and Paneque, et al. (2016), who also grew sunflower plants in soil treated with different doses and types of biochar. In both studies, the authors observed no difference in plant growth at lower doses of biochar. However, a large amount of biochar may harm plant growth as biochar will likely compete with plants for nutrients. 
Table 3. Stem diameter, plant height, shoot dry mass, and inflorescence dry mass of sunflower plants cultivated in a Ultisol amended with coconut shell biochar and sewage sludge biochar, either alone or combined in different proportions. *: means followed by the same letter in a column are not significantly different $(\mathrm{P}<0.05)$ by the Tukey Test.

\begin{tabular}{lcccc}
\hline Treatment & Plant height & Stem diameter & Shoot mass & Inflorescence mass \\
& ------------ & cm & --------- & \\
\hline Control & $90.6 \mathrm{a}$ & $8.94 \mathrm{a}$ & $217 \mathrm{~b}$ & $72.2 \mathrm{c}$ \\
$\mathrm{SS}_{60} \mathrm{CS}_{0}$ & $89.6 \mathrm{a}$ & $10.3 \mathrm{a}$ & $154 \mathrm{c}$ & $59.6 \mathrm{~d}$ \\
$\mathrm{SS}_{30} \mathrm{CS}_{0}$ & $92.7 \mathrm{a}$ & $10.1 \mathrm{a}$ & $231 \mathrm{~b}$ & $88.7 \mathrm{~b}$ \\
$\mathrm{SS}_{20} \mathrm{CS}_{10}$ & $94.7 \mathrm{a}$ & $9.50 \mathrm{a}$ & $269 \mathrm{a}$ & $83.5 \mathrm{~b}$ \\
$\mathrm{SS}_{10} \mathrm{CS}_{20}$ & $94.0 \mathrm{a}$ & $9.20 \mathrm{a}$ & $275 \mathrm{a}$ & $108 \mathrm{a}$ \\
$\mathrm{SS}_{0} \mathrm{CS}_{30}$ & $97.2 \mathrm{a}$ & $9.75 \mathrm{a}$ & $240 \mathrm{~b}$ & $74.9 \mathrm{c}$ \\
\hline
\end{tabular}

Source: Authors.

Additionally, biochar with high toxic volatile matter content such as SSB can reduce microbial activity, nutrient cycling, root development and, consequently, impair plant growth when applied at high rates (Gonzaga, et al., 2017). This was also observed in the present study when the treatment SSB60CSB0 was applied to the soil, which caused a significant reduction in the shoot (30\%) and inflorescence (17\%) biomass, indicating that, even though SSB presented high N, P, and ash content that could benefit plant growth, its high volatile matter content might have affected the plant performance due to the high application rate.

The application of 30-ton ha ${ }^{-1}$ of the combined biochar (SS20CS10; SS10CS20) significantly increased plant (27\%) and inflorescence $(50 \%)$ biomass.

Despite the amount applied, each biochar has likely contributed to specific soil changes, which somehow benefited plant growth. It has been reported that nutrient-poor biochar such as those originated from lignocellulose- rich feedstock, as in the case of the CSB, may have limited benefit on plant growth and needs an additional source of fertilizer. Therefore, it may be suggested that the SSB improved the availability of N and P. In contrast, the CSB increased water retention and improved soil structure, which caused a positive effect on sunflower plants. These results confirm our hypothesis that an adequate mix of different biochar that could serve both as a soil amendment, as a source of nutrients, and as a soil conditioner, for soil physical improvement can potentially cause a positive effect on plant growth. Even though the combined biochar application to soil did not influence plant high and colon diameter, it increased the shoot biomass and inflorescence, which seems a positive outcome since the commercially harvested plant part benefited from biochar. Therefore, more investigation should be performed on the combined application of different types of biochar to soils.

\subsection{Effect of biochar on chlorophyll content and plant nutrition}

The chlorophyll a (chl a) and chlorophyll b (chl b) content varied from 22-25 SPAD units and from 7 -10 SPAD units, respectively (Figure 1). The total chlorophyll values varied from 30-35 SPAD units within the normal range found in sunflower plants (35.3 units). Considering that, in general, the chl a/chl b ratio in most plants is around 3:1, our plants presented an imbalance, even in the control treatment (7.60:1), which was likely because plants grew under a greenhouse environment. 
Figure 1. Chlorophyll a, chlorophyll b, and total chlorophyll in the leaves of sunflower plants (Helianthus annuus $\mathrm{L}$ ) cultivated in a Ultisol amended with coconut shell biochar and sewage sludge biochar, either alone or combined in different proportions. *: means followed by the same letter in column with same color are not significantly different $(\mathrm{P}<0.05)$ by the Tukey Test.

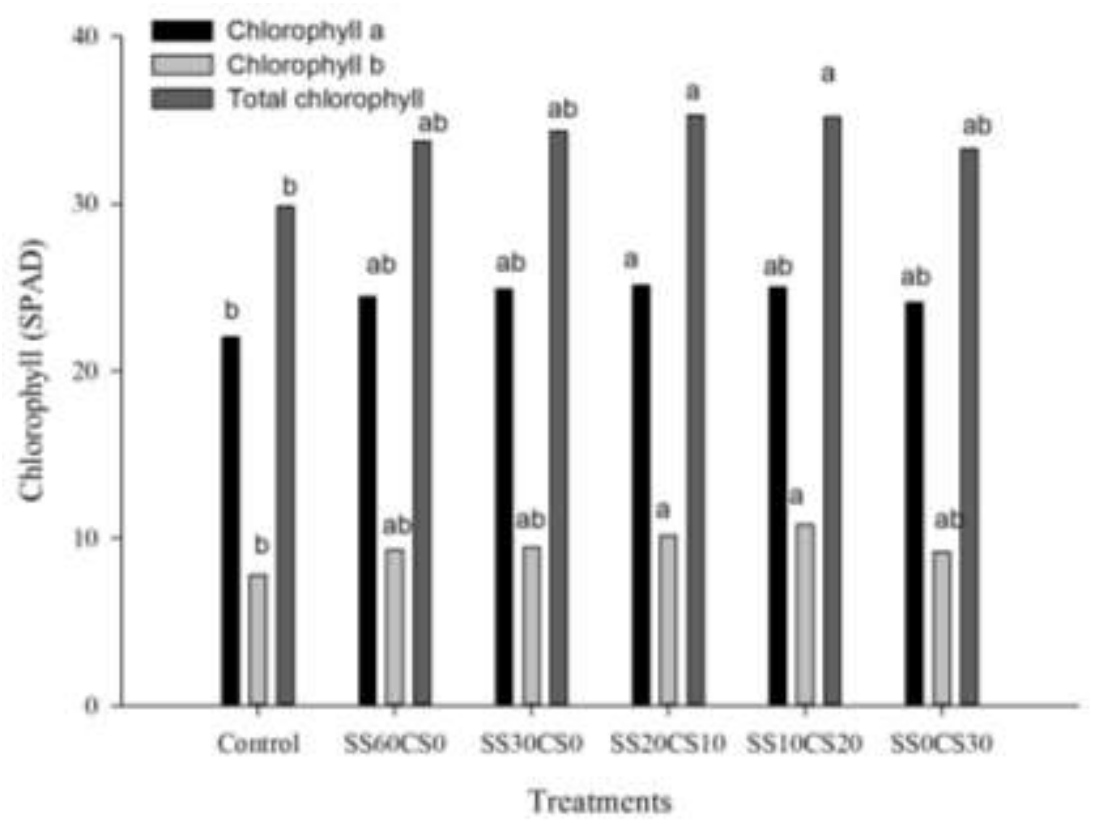

Source: Authors.

The combined application of the two biochars increased the chlorophyll content in the plants and increased the chl a/chl $b$ ratio from 7.60 (control soil) to 9.60 (mean value for the biochar treatments). Since this pigment is directly involved in the photosynthetic process, it can be related to the increase in plant biomass observed in the SS20CS10 and SS10CS20 (Table 3). The measurement of the leaf chlorophyll content in higher plants is frequently used to evaluate the plant health quality. Higher chlorophyll content indicates higher plant quality, which further translates into higher plant production. In our study, the sunflower plants were visually healthy throughout the cultivation cycle, as can be observed in the results shown in Table 3 and Figure 1.

Table 4 shows the concentrations of $\mathrm{N}, \mathrm{P}, \mathrm{K}$, and $\mathrm{Na}$ in plant shoot. The shoot $\mathrm{N}$ concentration varied among treatments and ranged from 19.3 to $35.7 \mathrm{~g} \mathrm{~kg}^{-1}$. Treatments with sewage sludge increased plant N, except SS10CS20, likely due to a higher amount of the CSB and a dilution effect caused by the increase in plant biomass. In fact, the application of coconut biochar alone significantly reduced plant $\mathrm{N}$ by approximately $17 \%$, whereas, at the same rate of application, SSB increased plant $\mathrm{N}$ by almost $20 \%$. This was likely because the SSB can act as a source of N, whereas the CSB is a sink, reducing the availability of N. 
Table 4. Concentration of nitrogen $(\mathrm{N})$, phosphorus $(\mathrm{P})$, potassium $(\mathrm{K})$, and sodium $(\mathrm{Na})$ in the leaves of sunflower plants (Helianthus annuus L) cultivated in a Ultisol amended with coconut shell biochar (CS) and sewage sludge biochar (SS), either alone or combined in different proportions. *: means followed by the same letter in a column are not significantly different $(\mathrm{P}<0.05)$ by the Tukey Test.

\begin{tabular}{lcccc}
\hline Treatment & Plant N & Plant P & Plant K & Plant Na \\
& --------- \\
\hline Control & $23.2 \mathrm{~d}^{*}$ & $3.69 \mathrm{c}$ & $0.62 \mathrm{~d}$ & $0.03 \mathrm{c}$ \\
$\mathrm{SS}_{60} \mathrm{CS}_{0}$ & $35.7 \mathrm{a}$ & $10.7 \mathrm{a}$ & $3.82 \mathrm{a}$ & $0.80 \mathrm{a}$ \\
$\mathrm{SS}_{30} \mathrm{CS}_{0}$ & $29.6 \mathrm{~b}$ & $6.96 \mathrm{~b}$ & $1.80 \mathrm{c}$ & $0.40 \mathrm{~b}$ \\
$\mathrm{SS}_{20} \mathrm{CS}_{10}$ & $27.8 \mathrm{~b}$ & $4.48 \mathrm{c}$ & $2.86 \mathrm{~b}$ & $0.33 \mathrm{~b}$ \\
$\mathrm{SS}_{10} \mathrm{CS}_{20}$ & $25.2 \mathrm{c}$ & $4.57 \mathrm{c}$ & $3.17 \mathrm{~b}$ & $0.08 \mathrm{c}$ \\
$\mathrm{SS}_{0} \mathrm{CS}_{30}$ & $19.3 \mathrm{e}$ & $4.89 \mathrm{c}$ & $3.84 \mathrm{a}$ & $0.06 \mathrm{c}$ \\
\hline
\end{tabular}

Source: Authors.

The use of sewage sludge in agriculture as a source of organic matter and nutrients, especially $\mathrm{N}$, has long been reported. However, some restriction remains due to the presence of pathogens that can cause environmental contamination. The pyrolysis process sterilizes the sludge and enables its safe application to soil. Even though some $\mathrm{N}$ might be lost through volatilization during the carbonization phase, the present study showed that the presence of SSB still contributes to increasing plant N concentration, suggesting that some fraction of $\mathrm{N}$ in the biochar is labile and can be absorbed by the plants. Additionally, $\mathrm{N}$ is an essential nutrient to oilseed plants such as sunflower because it is required in large amounts for protein formation. Therefore, the efficiency in acquisition and use of $\mathrm{N}$ by the plants observed in the treatment with SSB is of paramount importance for good sunflower productivity, especially in Brazil's northeast region, where most soils are of sandy nature and low in organic matter content.

The concentration of $\mathrm{P}$ in the aboveground biomass significantly varied $(\mathrm{P}<0.05)$ among treatments and ranged from 3.69 to $10.7 \mathrm{~g} \mathrm{~kg}-1$ (Table 3). Despite causing a reduction in the availability of P in soil (Table 2), the addition of CSB either alone or mixed with SSB did not affect plant P. However, application of $30 \mathrm{tha}^{-1}$ and $60 \mathrm{t} \mathrm{ha}^{-1}$ of SSB alone significantly increased the concentration of $\mathrm{P}$ in the plant by $80 \%$ and $90 \%$, respectively. The interaction of biochar with $\mathrm{P}$ has recently been investigated (Liang, et al., 2014; Xu, et al., 2016) and can shed some light on the importance of knowing the characteristics of both biochar and soil before biochar application, because this will dictate $\mathrm{P}$ fertilization and plant uptake. For instance, manure-derived biochar had a positive impact on $\mathrm{P}$ availability when applied to an acidic, low fertility soil (Liang, et al., 2014), probably through direct P release from the biochar, corroborating with the findings of the present study.

Conversely, plant-derived biochar, such as CSB, can indirectly influence P status in the soil through soil $\mathrm{pH}$ and microbial activity changes. Therefore, it can either increase or decrease P retention depending on the soil type and $\mathrm{P}$ concentration. Still, it is unlikely to supply enough $\mathrm{P}$ to plants. The increase in $\mathrm{pH}$ of acidic soils caused by biochar addition reduces $\mathrm{Fe}$ and $\mathrm{Al}$ 's concentration in soil solution, which makes $\mathrm{P}$ more available to plants. However, an excessive increase in $\mathrm{pH}$ can also reduce $\mathrm{P}$ availability through the formation of Ca-P complexes. Therefore, the application of plant-derived biochar to highly weathered soils will likely require better soil nutrient management to improve plant growth and productivity.

All biochar treatments increased the concentration of $\mathrm{K}$ in the plants, which ranged from $0.62 \mathrm{~g} \mathrm{~kg}-1$ (control) to $3.84 \mathrm{~g} \mathrm{~kg}$ 1, as following SS0CS30 $=$ SS60CS0 > SS10CS20 $=$ SS20CS10 > SS30CS0 > control. Interesting to note that both SSB and CSB 
are a good source of K; however, CSB is superior, as shown in Table 4. When applied at the same rate of $30 \mathrm{t} \mathrm{ha}^{-1}$, CSB and SSB caused a six-fold and three-fold increase in plant $\mathrm{K}$, respectively. The effect of biochar on plant $\mathrm{K}$ concentration was likely due to the increase in K's availability in soil (Table 2), which increased $\mathrm{K}$ uptake by the plants. The permanence of $\mathrm{K}$ from the biochar in soil is believed to be short-lived because of its high lability. Hence, it can be quickly absorbed by the plants as well as leached through the soil profile. However, with time, biochar can improve $\mathrm{K}$ adsorption capacity through the increase in CEC, which increases plant absorption efficiency and controls K loss from soil (Spokas, et al., 2011).

Plant $\mathrm{Na}$ concentration varied from $0.03 \mathrm{~g} \mathrm{~kg}^{-1}$ to $0.80 \mathrm{~g} \mathrm{~kg}^{-1}$. It was clear that biochar from sewage sludge or in combination with $10 \mathrm{t} \mathrm{ha}^{-1}$ of CSB (SS20CS10) significantly increased Na concentration within the plant. Even though Na levels in the plant were within the normal range found in most plant species, it could cause some competition with $\mathrm{K}$, resulting in nutrient unbalance and reducing plant growth. For that matter, the use of sewage sludge biochar should be used cautiously as a soil amendment.

Even though a combined application of SSB and CSB increased the plant N and K concentrations but not P, this was not a negative outcome since some studies have shown that biochar can reduce plant P concentration (Gonzaga, et al., 2021).

\section{Conclusion}

The combined application of coconut shell and sewage sludge biochar did not affect soil EC and oxidizable carbon; however, it significantly increased soil $\mathrm{pH}$ and the extractable concentration of $\mathrm{P}$ and $\mathrm{K}$ in the soil, which might have contributed to the increase in plant shoot and inflorescence biomass. This indicates that plants can benefit from the combined application of different types of biochar due to their different soil functions, such as promoting a better environment for plant growth and improving soil fertility. Biochar from coconut shell and sewage sludge can be a good source of $\mathrm{K}$ in the soil; however, coconut biochar is more efficient in increase soil $\mathrm{pH}$ and the availability of $\mathrm{K}$. Therefore, our results show that the use of these two biochars can become a valuable tool to neutralize soil acidity and as a source of nutrients, which are very important for small farmers in Sergipe. Due to the high variation of biochar characteristics, we suggest more investigation to test other types of biochar, their combined application in different proportions, and other plant species. For example, biochar from manure and other types of feedstocks frequently found in small rural properties should be tested to increase soil management and improvement alternatives.

\section{Acknowledgments}

This research was funded by the Brazilian National Research Council (CNPq).

\section{References}

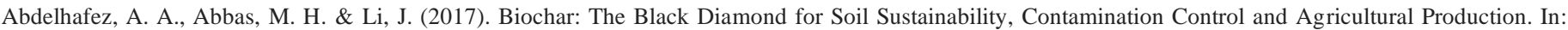
Engineering Applications of Biochar, http://dx.doi.org/10.5772/intechopen.68803.

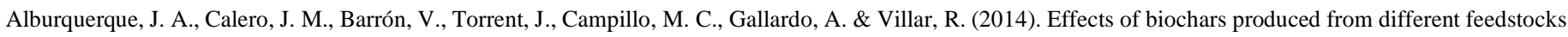
on soil properties and sunflower growth. Journal of Plant Nutrition and Soil Science, 177(1), 16-25. 10.1002/jpln.201200652.

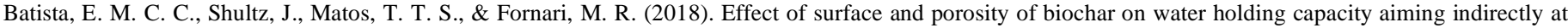
preservation of the Amazon biome. Scientific Reports, 8, 10677. https://doi.org/10.1038/s41598-018-28794-z.

Bremner, J. M. Nitrogen total. In: Sparks, D. L. (1996). Methods of soil analysis. Part 3. Madison, America Society of Agronomy, Madison. 1085-1121.

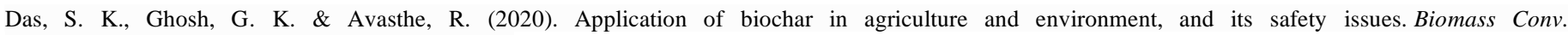
Bioref. https://doi.org/10.1007/s13399-020-01013-4. 
Research, Society and Development, v. 10, n. 4, e8910413848, 2021

(CC BY 4.0) | ISSN 2525-3409 | DOI: http://dx.doi.org/10.33448/rsd-v10i4.13848

Ding, Y.; et al (2017). Potential Benefits from Biochar Application for Agricultural Use: A Review. Pedosphere, 1-21. 10.1016/S1002-0160(17)60375-8.

Ferreira, D. F. (2011). Sisvar: a computer statistical analysis system. Ciência e Agrotecnologia, 35(6), 1039-1042. https://doi.org/10.1590/S141370542011000600001 .

Gaskin, J. W., Steiner, C., Harris, K., Das, K. C. \& Bibens, B. (2008). Effect of low-temperature pyrolysis conditions on biochar for agricultural use. Transactions of the ASABE, 51(6), 2061-2069. 10.13031/2013.25409

Gonzaga, M. I. S., Mackowiak, C. L., Comerford, N. B., da Veiga Moline, E. F., Shirley, J. P., \& Guimaraes, D. V. (2017). Pyrolysis methods impact biosolidsderived biochar composition, maize growth and nutrition. Soil and Tillage Research, 165, 59-65. https://doi.org/10.1016/j.still.2016.07.009.

Gonzaga, M. I. S., Silva, P. S. O., Santos, J. C. J. \& Oliveira Junior, L. F. G. (2019). Biochar increases plant water use efficiency and biomass production while reducing $\mathrm{Cu}$ concentration in Brassica juncea $\mathrm{L}$. in a Cu-contaminated soil. Ecotoxicology and Environmental Safety, 183, 109553. 10.1016/j.ecoenv.2019.109557.

Gonzaga, M. I. S., Santos, J. C. J., Almeida, A.Q., Ros, K. \& Santos, W. M. (2021). Farming practices and technologies that can increase and sustain production without ruining the ecosystem were promoted as an approach to addressing these concerns. Archives of Agronomy and Soil Science, 1-14. https://doi.org/10.1080/03650340.2020.1869215.

Hossain, M. K., Strezov, V., Chan, K. Y. \& Nelson, P. F. (2010). Agronomic properties of wastewater sludge biochar and bioavailability of metals in production of cherry tomato (Lycopersicon esculentum). Chemosphere, 78(9), 1167-171. https://doi.org/10.1016/j.chemosphere.2010.01.009.

Hossain, M. Z., Bahar, M. M., Sarkar, B., Donne, S. W. \& Ok, Y. S. (2020). Biochar and its importance on nutrient dynamics in soil and plant. Biochar, 2, 379-420. https://doi.org/10.1007/s42773-020-00065-z.

Liang, F., Li, G. T., Lin, Q. M., \& Zhao, X. R. (2014). Crop yield and soil properties in the first 3 years after biochar application to a calcareous soil. Journal of Integrative Agriculture, 13(3), 525-532. https://doi.org/10.1016/S2095-3119(13)60708-X.

Murphy, J. A., \& Riley, J. P. (1962). A modified single solution method for the determination of phosphate in natural waters. Analytica chimica acta, 27 (1), $31-36$. https://doi.org/10.1016/S0003-2670(00)88444-5.

Nelson, D. W., \& Sommers, L. E. (1982). Total carbon, organic carbon and organic matter. In: Page, A. L.; Miller, R. H. \& Keeney, D.R., eds. Methods of soil analysis: Chemical and microbiological properties. Part 2. Madison, Soil Science Society of America. 539-579.

Nsamba, H., Hale, S., Cornelissen, G., \& Bachmann, R. (2015). Designing and Performance Evaluation of Biochar Production in a Top-Lit Updraft Up-scaled Gasifier. Journal of Sustainable Bioenergy Systems, 5, 41-55. 10.4236/jsbs.2015.52004.

Paz-Ferreiro, J., Nieto, A., Méndez, A., Askeland, M. P. J., \& Gascó, G. (2018). Biochar from Biosolids Pyrolysis: A Review. International Journal of Environmental Research and Public Health, 15, 956. 10.3390/ijerph15050956.

Paneque, M., De La Rosa, J. M., Franco-Navarro, J. D., Colmenero-Flores, J. M., \& Knicker, H. (2016). Effect of biochar amendment on morphology, productivity and water relations of sunflower plants under non-irrigation conditions. Catena, 147, 280-287. https://doi.org/10.1016/j.catena.2016.07.037.

Pereira, A. S., Shitsuka, A. R., Parreira, F. J., \& Shitsuka, R. (2018). Método da Pesquisa Científica. UFSM. https://repositorio.ufsm.br/bitstream/ handle/1/15824/Lic_Computacao_Metodologia-Pesquisa-Cientifica.pdf?sequence=1.

Silva, F. C. D. S. (Ed.2). (2009). Manual de análises químicas de solos, plantas e fertilizantes. Embrapa Informação Tecnológica; Embrapa Solos.

Silva, M. I., Mackowiak, C., Minogue, P., Reis, A. A. M. F. \& Moline, E. F. V. (2017). Potential impacts of using sewage sludge biochar on the growth of plant forest seedlings. Ciência Rural, 47, e20160064. 10.1590/0103-8478cr20160064.

Soil Survey Staff. (2014). Keys to Soil Taxonomy. (12a ed.), Soil Survey Laboratory. National Soil Survey Center. USDA-NRCS, Lincoln, NE.

Spokas, K. A., Novak, J. M., Stewart, C. E., Cantrell, K. B., Uchimiya, M., duSaire, M. G., \& Ro, K. S. (2011). Qualitative analysis of volatile organic compounds on biochar. Chemosphere, 85, 869-882. https://doi.org/10.1016/j.chemosphere.2011.06.108.

Xu, X., Wu, Z., Dong, Y., Zhou, Z., \& Xiong, Z. (2016). Effects of nitrogen and biochar amendment on soil methane concentration profiles and diffusion in a ricewheat annual rotation system. Scientific Reports, 6(38688), 1-13. https://doi.org/10.1038/srep38688.

Yousaf, B., Liu, G., Wang, R., Abbas, Q. B., \& Imtiaz, M. (2017). Investigating the biochar effects on C-mineralization and sequestration of carbon in soil compared with conventional amendments using the stable isotope (C13) approach. Global Change Biology Bioenergy, 9, 1085-1099. 10.1111/gcbb.12401.

Yuan, H., Lu, T., Wang, Y., Chen, Y., \& Lei, T. (2016). Sewage sludge biochar: nutrient composition and its effect on the leaching of soil nutrients. Geoderma, 267, 17-23. https://doi.org/10.1016/j.geoderma.2015.12.020.

Yu, H., Zou, W., Chen, J., Chen, H., Yu, Z., Huang, J., Tang, H., Wei, X. \& Gao, B. (2019). Biochar amendment improves crop production in problem soils: A review. J Environ Manag, 232, 8-21. https://doi.org/10.1016/j.jenvman.2018.10.117. 